\title{
Rethinking the Post-Secular and Secular with Habermas and Ambedkar
}

Neue Perspektiven auf das Postsäkulare und Säkulare mit Habermas und Ambedkar

Perspectives nouvelles sur le séculier et le post-séculier avec Habermas et Ambedkar

\section{Kanchana Mahadevan}

\section{(2) OpenEdition}

\section{Journals}

Electronic version

URL: http://journals.openedition.org/ceg/2976

DOI: $10.4000 /$ ceg. 2976

ISSN: 2605-8359

\section{Publisher}

Presses Universitaires de Provence

Printed version

Date of publication: 26 April 2018

Number of pages: $103-118$

ISBN: 979-10-320-0160-8

ISSN: 0751-4239

\section{Electronic reference}

Kanchana Mahadevan, «Rethinking the Post-Secular and Secular with Habermas and Ambedkar »,

Cahiers d'Études Germaniques [Online], 74 | 2018, Online since 26 October 2019, connection on 26 November 2020. URL : http://journals.openedition.org/ceg/2976 ; DOI : https://doi.org/10.4000/ceg. 2976 


\title{
Rethinking the Post-Secular and Secular with Habermas and Ambedkar
}

\author{
Kanchana Mahadevan \\ University of Mumbai
}

\section{Faith and Reason: A Habermasian Rapprochement?}

Following Casanova, Habermas's post-secular proposal can be understood via the secular in several ways. ${ }^{1}$ A re-sacralization of society, against a common temporal space between believers and non-believers; or a return to the religious worldview as opposed to one independent of religion. It also denotes the public use of religious convictions, symbols or images. But these conceptions of the post-secular are based on the Western model of secularization, with modernity's separation of state, economy and science from religion, decline of religious beliefs and their relegation to the personal (Casanova 2013: 34). By opposing their resulting secular commitments to abortion and de-criminalization of homo-sexuality, Christian fundamentalists disclose "conflicting value orientations - God, gays and guns..." (Habermas 2008: 117). Positioning itself in the legacy of Enlightenment tolerance to contest Islam, Christian fundamentalism combats the same legacy's world-view of science and technology. Western religious extremism considers the complex relationship between faith and reason as a "Kulturkampf between radical multiculturalism and militant secularism” (Habermas 2009: 70). Against assimilation as rootlessness, espousals of faith propagate cultural relativism critiquing the abstraction of universal reason. Alternatively, "Enlightenment fundamentalists" (ibid.: 73) defend their ground with the incommensurability of diverse religious world-views against an impartial dispassionate perspective. As a response to the challenges of Christian fundamentalism and new religious identities introduced to the West through globalization and migration, the post-secular is a resistance to Western secularization and secularism. Habermas's post-secular is also driven by the inadequacy of secular scientific reason's objectification of human nature in genetic engineering (Cooke 2010: 237).

However, a singular definition juxtaposing the secular and secularization with Western modernity is problematic in privileging European exceptionalism as a universal norm. For instance, unlike Europe, secularism in the United States

1. See Casanova (2013: 28-30) and Cooke (2010: 236). 
does not imply a decline of religion. Moreover, Europe does not exhibit a homogeneous religious decline. ${ }^{2}$ Casanova detects an increasing secularization of Western and non-Western societies with the advance of science and technology (Casanova 2013: 44). Rather than with its revival, ${ }^{3}$ Europe is "obsessed" (ibid.: 45) with religion's public role. Casanova further argues that Habermas's attempt to usher in a public dialogue between reflexive secular reason and religion needs to acknowledge that religion was never entirely abandoned (ibid.: 48). The secular / post-secular dyad, thus, opens up the possibility of an interface between religious and non-religious (secular) discourses.

According to Habermas, a law that is open to all citizens cannot privilege the secular over the religious, or vice versa (Habermas 2007: 260). Religion plays a substantive role in organizing everyday practices and ends for its community through world-views (ibid.: 259). ${ }^{4}$ Yet it loosens hold over the members of its community in their role as political citizens. This split can be addressed only through dialogue. It requires that non-believers take the claims of believers seriously. And vice versa. Both secularization and fundamentalism prohibit such a dialogue. Speaking across the religion-secularism divide, Habermas suggests that certain conditions be fulfilled for dialogue. ${ }^{5}$ Thus, the non-religious domain of science, politics and morality have the responsibility of accepting claims based on faith, while the religious are responsible for accepting the fallible results of natural reason, egalitarianism, law and morality. Thus, Habermas recommends that the religious and the secular communicate to resolve the challenges confronting the post-secular age.

Habermas is aware of the objection that given the totalizing world-view of the religious minded, it is quite possible that they become incapable of suspending their religious belief - even temporarily - to listen to the secular point of view or those of other religions (Habermas 2008: 114-147). Further, those with faith can articulate their argument in religious terms knowing fully well that only secular reason is upheld in institutions such as courts of law. Hence, the secular minded have to learn from the religious without dismissing their claims as irrational from the outset. Habermas allows for religious voices at the level of informal communication in the political public sphere. He suggests that religious content be eradicated from official parliamentary documents from the perspective of impartiality (ibid.: 131). But to be included in the formal political sphere they have to be translated to a commonly accessible language to avoid majoritarianism. This requires that religious citizens learn to relativize

2. Casanova notes that it is the highest in France, the Czech Republic and East Germany. In correlating secularization with modernization, Habermas follows Norris and Inglehart who have largely focused on Western European countries (2013: 41). He argues that this co-relation is weakened in contexts of economic underdevelopment and secularization such as China and American religiosity and economic development (ibid.: 42).

3. Casanova notes that church attendance in Western Europe has been diminishing since the 1950 s (ibid.: 37).

4. Following Rawls, Habermas terms this as a comprehensive doctrine (see Habermas 2007: 259).

5. This is in keeping with his earlier writings on communication. 
their cognitions. Such a "modernization of religious consciousness" (ibid.: 140) emerges while faced with a plurality of faiths, modern science and positive law. Rather than modern scientific methods certifying them as authentic, religious convictions are justified from within religion itself. Habermas notes that this requires that an "arduous work of hermeneutic self-reflection must be taken from within the perspective of religious traditions" (ibid.: 137). According to Habermas, such a learning process has to take place within the community of religious believers as theology once upheld.

Habermas calls for reinterpreting the sacred so that it becomes accessible to foster mutual learning with the secular. But this "cognitive burden" (ibid.: 138) is not confined to the religious alone. The secular-minded have to develop an attitude of openness towards their religious counterparts as well. Against the laicist approach, which believes that religions have no role to play in the public reason, the secular-minded will have to learn that it is possible to learn from religion. Secularism has to give up its naturalism to think in a 'post-metaphysical' (ibid.: 140-143) way; such thought does not merely rely upon the tradition of philosophical argumentation. Yet scientific arguments cannot be countered by religious claims, but from within the purview of science itself. Since the Axial Age, human beings acquired greater agency in the transition from muthos to logos via philosophy and religion. Further, Habermas acknowledges that the Western philosophical legacy has learned much from religious traditions of Christianity and Islam. According to him, the "cognitive substance" (ibid.: 142) of key global religions is not exhausted. ${ }^{6}$ Hence, religions can claim a place in the framework of modern reason. He redefines post-metaphysical thinking as learning from religion without taking sides. Such thinking acknowledges the difference between a conviction of faith and of argument (that is publicly criticized). For Habermas, such a complementarity enriches public deliberation with ambivalence and reflexivity (ibid.: 143).

Habermas's expansive notion of democratic deliberation includes a wide range of validity claims such as moral, ethical, pragmatic and even religious ones (Cooke 2010 and 2013: 268-69). It differs from moral deliberation, in regulating a limited frame of reference such as institutions and not adhering to strict universality. However, as Cooke notes, Habermas continues to harbor Western secularist apprehensions regarding religion by separating its claims from reason. He maintains that since religious reasons are not universally accessible, they cannot be a part of formal legislation. But as a part of informal deliberating publics, religion might lead to disagreement (Habermas 2008: 139). For the secular and the religious have their own internal grounds for justification; religious claims based on revelation and dogmatic authority might not be able to speak to the secular. Cooke rightly observes that even secular philosophy has its share of dogmatic “bed rock” claims such as Descartes's cogito or Kant's autonomy (Cooke 2013: 254-55). Yet, these dogmas are not infallible and non-negotiable, but core-convictions or "riverbeds" (ibid.: 255) that can be

6. Habermas (2008: 143) compares religion to art for its non-discursive dimension. 
challenged, reviewed and reinterpreted in unpredictable ways. This requires that Habermas go beyond translating religious claims for the secular minded. Such a privileging of the secular replicates modern Western political theory's neglect of religious traditions. Deliberative processes can be motored by non-deliberative processes to bring about a change in perception. Cooke herself suggests that revelation need not be divine or other-worldly, but could mean a "perceptual shift" (ibid.: 259) that is not necessarily cognitive or a stand-alone argumentative discourse (ibid.: 256-62). Indeed, rational argumentation is connected to nonargumentative disclosures ${ }^{7}$ from lived experience, involving factors such as rhetoric, choices, translations and empirical descriptions. They are not cognitive or modes of internal justification akin to symmetrical argument. Instead, as external factors they facilitate shifts in perception that enable disclosures to critique and transform existing beliefs.

Cooke contends that Habermas's post-metaphysical approach does not critically gauge the claims of religion, but only engages with them (Cook 2010: 241). One could argue that this is inevitable given that the post-secular is anchored in Western secularism (Casanova 2013: 48). For Habermas, reason is inevitably public, while faith is private so that they are precluded from mutual learning. As Rathore argues, Habermas's “revivalist endeavor seems moreover, a rather conservative one..." (Rathore 2010: 78) in retaining the Western liberal dichotomy between religion and politics. Habermas's neglect of the social dimension of religion also disregards possibilities for multiple religions to coexist in tolerant ways. This is a consequence of his acknowledging Western nations (having undergone secularization) at the cost of excluding the nonWestern world for post-secularity (ibid.: 82). As Rathore observes, this does not prevent Habermas from referencing Hinduism, Buddhism and Islam (ibid.: 82) or Hindu extremism (Habermas 2008: 114). Habermas mentions the possibility of religious family laws as alternatives to civil law in Israel and Islamic nations, but does not turn to concrete contexts of their materialization (Habermas 2008: 115; Rathore 2010: 81). A shift to Indian secularism debates illustrates the terms of a dialogue between faith and reason in the context of religious diversity. It also calls into question Habermas's certitudes of the secular and the post-secular.

\section{Indian Secularism as 'Distinct's}

Bhargava, one of the leading thinkers on the debate on Indian secularism, remarks that India has always been post-secular (Bhargava 2015: 110-111). In the Indian context, religion was always a source of values coexisting with the non-religious; hence, democratic deliberations have included religious claims. Bhargava's remark is an attempt to draw attention to the difficulties of

7. Cooke (2013: 258) rightly notes that such disclosures are a part of practical reasoning and not necessarily restricted to religious practice.

8. This term derived from Bhargava (2007) will subsequently be used without quotes. 
oversimplification in transposing Western concepts to the Indian context. There are crucial differences in the way religion, secularism and the state are addressed by Indian constitutional liberalism. Bhargava's simultaneous plea for the distinct nature of Indian secularism encompasses an equal respect for all religions and a principled distance from religious multiplicity (ibid.: 120-134). The intractable divide between religion and the secular province of state / politics / law is absent in India. Indian secularism(s) - with their tensions - bring religious discourse(s) to public life. Principled distance maintains state neutrality towards religion. But it also mediates to reform inhuman religious practices, such as the Hindu practice of caste discrimination. It upholds the descriptive fact of religious diversity as normative through differential treatment of minority religions. With centuries old overlapping of soteriologies and practices, religion in India is neither confined to personal piety, nor compartmentalized (ibid.: 117-118). A glance at debates on religion and state in India discloses shades of the postsecular, while offering a distinct account of secularism so that the demarcation between the secular and the post-secular becomes virtually impossible.

Since India did not undergo the Western process of secularization, religion has always been central to political debates. However, unlike post-secular "revival", religion in India is not a return, as it was always present in the public sphere. India did not have a seat of religious authority nor an official religious doctrine like Christianity. Religious groups such as Hindus and Muslims or Hindus and Buddhists were not compartmentalized in pre-colonial India. Indeed, even the materialistic traditions like Carvaka, which critiqued the very world-view of gods, prevailed. Pre-modern India reveals a co-habitation and intersection of secular and other world-views. Free movement across religions was possible without relinquishing the original religion. ${ }^{9}$ Further, state rule was not linked to any of the prevailing religions during pre-British, colonial or modern India. Several systematic debates on secularism have taken place in India since its independence. Rather than anticipate Western post-secularism's tolerance towards religious diversity and inclusiveness, these debates redefine the secular (Bhargava 2015; Chandhoke 2015). Thus, Indian secularism's entrenchment in religious pluralism and public discourse makes the post-secular redundant.

The British colonial project of codifying Hindu and Muslim family laws in the 18th century had governmental motives. During the 19th and 20th centuries, nationalist leaders examined the relationship between religion and public institutions in the context of its religious multiplicity. Indian political leaders (who were also thinkers) deliberated over secularism immediately after independence from the British in 1947, while academicians debated its Indian specificity in the aftermath of the Hindu right and communal riots in the 1980s. Indian law accommodated minority rights and multiple personal laws, alongside reform. Secularism was not about demarcating the religious from the

9. Bhargava notes that Hindus who became Buddhists / Jains did not quite give up their original practices (see Bhargava 2015). 
non-religious, nor was it about religion as private piety; it was instead about accommodating pluralism and modernizing religious traditions through critique.

The government tried to reform religion, but retreated to its broader civilizing mission with the consolidation of its rule in 1858. The Hastings Resolution in 1772 upheld religious textual authority as the basis of law to standardize Hinduism and Islam under the influence of Orientalism (Menon 2007: 75). ${ }^{10}$ Indian nationalist elite leadership (of diverse political persuasions) resisted foreign intrusion in cultural reform and Christian missionary proselytization; but they subscribed to the colonial privileging of texts. The textual traditions recovered were digests of rules, rather than critical and creative commentaries (ibid.: 76). They endeavored to model Indian religions after Christianity and were deeply influenced by Western philosophy. Hence, their reforms appealed to evidence in religious texts, rather than secular reason. For instance, rather than argue that Sati was inherently unethical, Raja Ram Mohan Roy argued that it had no scriptural sanction (ibid.). ${ }^{11}$ This led to the neglect of popular syncretic non-textual traditions, in which Hindus worshipped at Sufi shrines and Muslims at those of Hindus. These public sites of worship and pilgrimage - local shrines, festivals, fairs - were sidelined by both the British and the nationalists (ibid.: 77). ${ }^{12}$ This neglect also overlooked diversified public spaces where Indian masses from all communities and castes mingled (ibid.:). It replaced this with the culture of consumption, which circulated standardized images of Hindu deities that integrated colonial technology through advertising. In the 20th century, the British passed laws pertaining to Muslim Personal Law and Marriage in 1937 and 1939 (Patel 2009; Mahmood 2017) and its Hindu counterpart with the Child Marriage Restraint Act in 1929 (Menski 2006). But these changes were the outcome of nationalist activism, rather than colonial governmentality.

In the post-independence era, there were state legislations against the Hindu practices of untouchability and inhuman ritualism that were included in the Constitution in 1952. ${ }^{13}$ The Hindu Code Bill in 1955 advocated reforms in Hinduism by allowing women inheritance, permitting divorce and inter-caste marriage. The Muslim Women (Protection of Rights on Divorce) Act in 1986 allowed divorced Muslim women the right to maintenance under the Criminal

10. However, since Hinduism did not subscribe to one sacred text, local scholars brought in their own subjective interpretation in the name of codification (Menski 2006: 244-246). The government gave up the official task of codification of both Hinduism and Islam by the 19th century. Though they effected some changes in Hindu and Muslim family law, substantive reforms - of Hinduism - were undertaken after independence.

11. Sati or the practice of widow immolation was outlawed in 1829. However, nationalists argued that Sati was against Hinduism itself so that the British attempt to civilize Indians became redundant. See Menon for a detailed discussion of both Hindu and Islamic reformers as erasing their plural practices by turning to texts under the Orientalist influence (Menon 2007: 77). Also see Fernée (2014: 106-148) for a detailed account of Indian nationalist movement in the 19th century, where both Hindu and Islamic reformers sought uniformity in their respective traditions.

12. Also see Mohammad (2013).

13. See Chatterjee (1994: 1770) for a detailed account. 
Procedure Code. ${ }^{14}$ Reform was justified through inclusiveness of gender and caste within each religion, rather than civil rights as they pertained only to a specific religious community. Thus, the political apparatus took upon itself the task of interpreting religious doctrine and ritual. In this, the principles of religious freedom and equality were also put to test, as was the principle of neutrality towards all religions. Thus, Habermas's split between faith and reason is irrelevant in the Indian institutional context of law.

The Indian state was committed to secularism without being anti-religious. The post-independent period witnessed an ongoing sustained debate between Indian leaders on religion, state and secularism, as the constitution was drafted, namely the Constituent Assembly debates. ${ }^{15}$ Some argued for secularism as a divide between religion and politics, while others suggested that it be abandoned given the inevitable existence of religion in the public domain. There are those who spelled out a via-medium position between these two to work out a middle path of state neutrality to religious vocabulary, given India's religious pluralism. But they did press for reform of religion through interventions from state and civil society in the absence of centralized regulatory bodies like a church.

During the second phase of the secularism debate (since the 1980s) there has been an academic response to increasing religious extremism by Bhargava, Thaper, Alam Bilgrami, Madan etc. ${ }^{16}$ Proponents of secularism argued against the universalization of Western secularization and advocated India as an alternative model. Others, like Madan and Nandy, were critical of the very concept of secularism; they saw secularism as resting on Western modernization and instrumental rationality, with the added burden of colonization. It resulted in the development of big dams through the state and corporate bodies at the expense of poor and social marginalized local communities. They additionally argued that secularists failed to see the progressive and transformative role of religion in community life in India. Thus, for the critics, secularism was a problematic colonial statist remnant; it neglected indigenous overlapping religious communities and practices. However, one cannot consequently concede to Chatterjee that secularism in India is inevitably linked to Western genealogies, without an autonomous conceptual legacy (Chatterjee 1994: 1769).

Defenders of secularism such as Bhargava argued for a 'distinct' Indian model $^{17}$ (Bhargava 2007). It accommodated the Gandhi-inspired concept of according equal respect to all religions by appreciating pluralism and fostering dialogue. ${ }^{18}$ But it also came to mean what Bhargava terms as a "principled intervention', when the law curbed the excesses of religion, such as the untouchability in Hindusim (through citizens' activism). As a result of the state's

14. As Patel (2009) notes, it was controversial on account of this.

15. See Bhattacharya (2016) and Jha (2002) for details.

16. See their essays in Bhargava (1998).

17. Although the singular is used, one can discern at least two models of secularism.

18. Also characterized as 'sarva dharma samabhava', it has been incorporated in the Indian constitution. 
critical intervention, religious pluralism - along with agnosticism and atheism - found place in the law. Indian secularism reconciled reason and faith, making redundant Habermas's post-secular revival of religion. Its claims were a part of public discourse precisely because of religion's social character. India did not undergo the European process of secularization, which compartmentalized religion, separated it from politics and restricted it to individual conscience. ${ }^{19}$ Rather, religious imagination continued to be a part of social and public life in India, despite the advent of colonial modernity. ${ }^{20}$ Religion in India, unlike Habermas's Enlightenment account, articulates the moral virtues of community life while pursuing public goods; this is because of its inherently communitarian character. Traditional Indian religion ranges from moral order (dharma) and belief (mazhab) to fellowship (panth) or community (qaum) for both Hindus and Muslims (Juergensmeyer 2011: 193). As mutually dependent dimensions of Indian secularism, reason and faith are not locked in a battle against each other.

Such an enmeshing of religion, society and politics in the Indian context renders superfluous standard accounts of religious extremism as polarized from the secular state such as Juergensmeyer's (ibid.: 186). Such analyses discern religion's loss of control over the political as the outcome of pursuing secularism with a religious fervor under the influence of colonization. Juergensmeyer defines the period from 1945 to 1990 as the 'golden era' of secular nationalism, both in the Western and non-Western worlds. He cites nationalist leaders, like Nasser in Egypt and Nehru in India, as upholding Western secularism in the interest of modern nationalism; minority religions and underprivileged castes found solace from majoritarianism (ibid.: 190-91). ${ }^{21}$ However, this account leaves out the specificity of the Indian situation, where secularism and religion did not compete for social stability as "interventions in modernity" (ibid.: 198). Indian secularism is not a critique of religion or an "Enlightenment fundamentalism" (Habermas 2009: 71) as it is in the West, but rather accommodates both faith and reason.

Analogously, religious extremism in India is not a critique of reason or secularism as it is in the West. The consolidation of colonial rule in 19th century India introduced commodities through urbanization, industrialization, corporatization of finance and institutionalization of art and education (Jain 2017: 51). Commercial art circulated Hindu images to advertise soap, fabric and cigarettes. Hindu imagery circulated - without acknowledging

19. As Casanova notes, European societies have transcended religion to "a point of no return" (Casanova 2013: 44), whereby religion has ceased to matter.

20. A visual art exhibition Indian Popular Visual Culture: The Conquest of the World as Picture curated by the Indian artist Jyotindra Jain at the Dr. Bhau Daji Lad Museum in Mumbai from April 09-30th, 2017 depicts the all-pervasiveness of religious images in popular culture. Jain points to the mass availability of such images through the printing press initiated by the artist Raja Ravi Varma. See Gehl (2017).

21. "Not only Western academics but also a good number of new leaders - especially those in the emerging nations created out of former colonial empires - were swept up by the vision of a world of free and equal secular nations" (Juergensmeyer 2011: 190). 
its intersections and roots in other religions - and created an impression of autonomy. Although indigenous artists such as Ravi Verma were pivotal to this process, much of the advertising was done by the British themselves. Such a mass production and consumption of Hindu deities through technology is one of the factors that set the stage for Hindu extremism, which integrated with modern Western secular science and technology. The Hindu right emerged as an alternative in the anti-colonial struggle to the liberal Indian National Congress and the Left (Brekke 2012). Thus, the Hindu right cannot be fitted into secularism and religion as rival nationalist (legitimized state) and religious (illegitimate) imaginings of violence, over issues of identity, loyalty, habit in public institutions. In one of his rare comments on the non-European world, Habermas opines that "in our post-colonial immigrant societies, discrimination against minorities is usually rooted in prevailing cultural prejudices that lead to a selective application of established constitutional principles" (Habermas 2008). Thus, Hindu majoritarianism exercises its hold through a selective use of the constitution and ideals of modernity.

Following Chatterjee, Hindu nationalism does not challenge the Western notion of a secular state (1994: 1768-69) as separate from religion. It is "perfectly at peace" (ibid.: 1768) with modern Western ideals of state and nation in whose name it advances its agenda as development. Rather than oppose secularism, it advances Hinduism as the most tolerant religion and dismisses Islam as intolerant. It mobilizes the state's secular legal apparatus to alienate minorities through bans on beef eating or by generating debates on gender justice by referencing Islam. It questions the credentials of those upholding the minority's right to religion or its own critics as "pseudo-secular". In this respect, the Hindu right is different from Islamic extremism, which decries secularism as a Western ruse. ${ }^{22}$ Religious extremism in India advances a homogeneous notion of religion as a centralized set of practices in keeping with the Western approach. The latter absolutized religion to make it immune to dialogue in the course of inflicting Western instrumental reason's model of secularism. From a normative point of view, Indian secularism offers a buffer against Hindu religious extremism.

The Indian context, thus, reveals secularism to accommodate faith, while extremism accommodates secularism. Extremism and secularism in India differ in that the former homogenizes religion via Western instrumental reason, while the latter - in keeping with syncretic legacies - pluralizes religion without resorting to Western instrumentalism. Indian secularism's effort is embedded in centuries of religious pluralism and critical interrogation of faith, some of which have been legalized in the post-independent era. Thus, there are several histories of secularism in India which demonstrate, against Habermas, that the line between religious and the secular is blurred. Since Indian secularism is heterogeneous, religious argument is integrated in the public sphere, while religious pluralism is defended. However, religious reform is also stifled when these gains are threatened by exclusions of caste and gender. Thus, Indian debates on secularism

22. Also see Bhatt (2001) for an analogous discussion of the Hindu right. 
open an alternative way of thinking about religion in terms of social solidarity. However, they have not paid adequate heed to a critical appraisal of religion, which is a precondition for reform that enables faith and reason to "live together in a self-reflective manner" (Habermas 2008). One needs to turn to Ambedkar for such a critique.

\section{Ambedkar: Beyond Post-Secularism and Extremism}

The academic debate on Indian secularism neglects a critical hermeneutics of religion. It highlights India's spontaneous coexistence and overlap of religious communities, in light of which secularism de-absolutizes faith and valorizes religious pluralism. ${ }^{23}$ On this view, India was always secularist (Bilgrami 2016: 28). But this picture of tolerance overlooks the larger failed solidarity, given the "inner violence" (Menon 2007: 60) of caste discrimination endorsed by Hinduism. ${ }^{24}$ The colonial period exacerbated caste divides with Hinduism's consolidation as a unified textual tradition. Hindu social reformers in their nationalist zeal failed to see textual evidence supporting caste hierarchy in their homogenized versions of scripture. ${ }^{25}$ They failed to discern communal disharmony as "...the highest stage of casteism" (ibid.: 61). Hinduism's caste-driven refusal to share religious and non-religious practices in public social contexts also manifested as a failure to peacefully coexist with non-Hindu religions like Islam (ibid.). Statist legal reforms in religion introduced by both colonial and post-colonial administrations were oriented to eradicating caste ${ }^{26}$, introducing gender parity ${ }^{27}$ and instilling communal harmony ${ }^{28}$. But the law could not achieve these goals satisfactorily, given the increasing divisiveness in society. The gradual erosion of informal religious syncretism demonstrated the limits of depending on spontaneous social formations. For "distinct" Indian secularism to materialize, caste equality has to precede equality of faiths in civil society. This is possible only through free critical thought and practice. Thus, Hindu texts and practices need to be critiqued, while bringing them into contact with non-religious ideals, and other religions.

In this context, Ambedkar's arguments, neglected by Indian academic debates on secularism, are significant. An architect of the Indian constitution, and a member of the erstwhile 'untouchable' caste of India, he negotiated both

23. This has been derived from Gandhi, who as Bilgrami (2016: 28) notes, was not an explicit advocate of secularism.

24. Hinduism stratifies society into four castes / groups on the basis of birth as follows: brahmins (priests), kshatriyas (warriors), vaishyas (merchants) and shudras (menial laborers). There are rigid rules governing their social interaction. The caste of menial laborers were looked down as 'untouchables' for several centuries.

25. Reformers such as Raja Ram Mohan Roy, Vivekananda, Balgangadhar Tilak.

26. The Madras Temple Entry Authorisation Act of 1947 was emulated in other parts of India to become a law against untouchability.

27. The Hindu Code Bill was instituted in 1955 after an enormous struggle.

28. Articles 25-28 of the Indian constitution allow for religious freedom, propagation and tolerance. 
religious faith and reason by making traditions critical (Rodrigues 1993), while reconstructing them. His own family followed the syncretic religious tradition of the Saint Kabir (ibid.: 303) ${ }^{29}$ He did not critique and defend Hinduism by appealing to its principle of abstract oneness in the manner of other nationalists. For Ambedkar the caste system was not a superficial aberration in Hinduism that could be reformed through an appeal to consistency with other internal Hindu values of pluralism or oneness. ${ }^{30}$ He diagnosed a theoretical defense of caste in Hindu doctrine that was both the cause and outcome of casteist practice. It, thus, challenged spontaneous religious grassroots syncretism. Given religion's all-pervasive hold on people's thought and practice in India, "there is no act of the Hindu which is not covered or ordained by religion" (Ambedkar 2010: 20). Thus, Ambedkar begins with a critique of religion to infuse civil society with egalitarianism from which respect for plural faiths can emerge (see Ambedkar 1990).

His radical egalitarian critique of religion reveals that Ambedkar did not restrict himself to statist secularism. ${ }^{31}$ The law cannot transform the mental domain of beliefs or the social one of practice, though it could be a catalyst for these domains. Such transformation can only be initiated by society. As a bond between society and politics, religious inequality impacted social life and political participation. Underprivileged Hindu castes were hindered from political participation due to centuries of social alienation. Hence, the sphere of religion in civil society needed transformation to act as a constructive catalyst. Ambedkar was apprehensive about inserting the terms 'secular, federal and socialist' in the Preamble to the Indian constitution. ${ }^{32}$ He believed that the constitution could not give a blueprint for social specificities; in a democracy, people would organize their lives in the way they see fit. For Ambedkar, civic culture would have to be compatible with modern ideals of liberty, equality and fraternity or fundamental constitutional rights without state interference. India's exposure to modern ideals neglected both equality and solidarity (Ambedkar 2002: 189); it had to redefine them in its own way through syncretic social practice. Hence, for Ambedkar the formalization of concepts such secularism that is integral to everyday beliefs in India was redundant; ${ }^{33}$ rather than the state, it was society which had the onus of defining itself as secular. He argued that society could be held together through either the sanction of law or morality (Ambedkar 1990). Morality is enforced through religion at the level of mass

29. A fifteenth century saint, Kabir, integrated Hinduism with Islam.

30. Nationalist reformers followed this path.

31. Bilgrami notes how the secularism espoused by India's first Prime Minister (Nehru) postindependence is statist, since it encourages state intervention in retaining communal harmony (see Bilgrami 1994). Consequently, he notes that religious tolerance has been tenuous and has encouraged Hindu extremism. In contrast, the Gandhian paradigm assumes a spontaneous mutual respect for all religions; a point noted by Bilgrami himself (see Bilgrami 2016). Ambedkar attempts to link civil society with state through a reflective process of critique. Unfortunately, Bilgrami does not engage with Ambedkar like many other thinkers on secularism.

32. The Constituent Assembly debates in Parliament November 15, 1948.

33. Ambedkar did not mention secularism, his mention of socialism is extended to secularism. 
society; its sacredness implies that it cannot be violated, it has a deeper force than legality in fostering egalitarian social relations. Its wide reach allows it to overcome social barriers and promote equality. The force of religion prevents it from degenerating into group morality. ${ }^{34}$

Ambedkar suggests a philosophical approach to the study of religion. The teachings of specific religions, not encompassed by an over-arching philosophy, need critical assessment. A descriptive and normative study, philosophy of religion differs from the comparative approach that holds all religions as equally worthy (Ambedkar 2010: 21-22). ${ }^{35}$ Like formal equality, such a leveling ignores internal hierarchies, which inhibit religions from peacefully coexisting together. Such an abstract equality also overlooks that religions are not eternal systems frozen in time, but change and adapt to diverse historical contexts. In his philosophy of religion(s), Ambedkar maps the religions' unacknowledged revolutionary shift from the ancient to the modern context (ibid.: 9-18). The external transition from religious dogma to scientific reason via Darwinism and the Copernican revolution - a subject of constant discussion - challenged religion's totalizing hold over scientific thought and restricted it to the individual and community (ibid.: 8). But the subsequent obsession with secularization ignores the internal revolution in the structure, substance and norms of religion. Modern religion changed its criterion from utility to justice. Ambedkar observes that the ancient approach upheld the notion of divine governance, while the modern perspective dwelt on the human aspiration for the divine. For the moderns, divinity was not confined to specific groups, but belonged to the world itself so that the divine force was responsible for the welfare of humanity at large. Religious identity was linked to freedom, so that change in nationality did not require change in religious identity. Ambedkar saw this as opening up a reasoned relationship to religion, without fearfully or superstitiously submitting to a transcendent force. Unlike ancient religion that evaluated conduct with utility, modern religion turned to justice (ibid.: 19), a "current notion of what constitutes moral good" (ibid.: 20). Ambedkar proposes a critical interpretation of religion so that it is compatible with freedom, equality and fraternity. Conversely, he also critiques modern interpretations of freedom, equality and solidarity from the perspective of the Buddhist religious ideal of solidarity.

Citing scriptural evidence, Ambedkar argues that Hinduism has to confront the problem of exclusion while appraised through justice, and related norms of equality, liberty and fraternity. Since "Hinduism asserts the validity of a caste based social order and opposes equality" (ibid.: 22-23), Ambedkar concludes that it denies social, economic or epistemological equality as the ground of self-respect (ibid.: 37). It does not acknowledge liberty as the condition for religious choice. According to Ambedkar, there is an absence of "fellow-feeling" (ibid.) in Hinduism because of its hierarchical division of human beings into

34. See Ambedkar (1957: 215-221; 232-235).

35. As Gokhale notes, against Gandhi's view of equality of religions, Ambedkar upholds a social view which enables critique of and within religion (Gokhale 2008: 112). 
a caste order (ibid.: 37-39). ${ }^{36}$ Hinduism's dogmatic face has prevented it from changing the plight of millions people belonging to underprivileged castes $^{37}$ or constructively impacting other religious groups around it. Hinduism for Ambedkar "is overwhelmed with the fear of pollution. It has not the power to purify. It has not the impulse to serve [...]" (ibid.: 80).

Besides the modern concept of justice, Ambedkar's critique of Hinduism also appeals to the Buddhist critique of caste ${ }^{38}$ and its virtues ${ }^{39}$ of compassion and fellowship. This is buttressed by the Buddha's non-essentialist approach to the self (Ambedkar 1957: 182-186), as well as his stress on non-dogmatism, nonabsolutism and non-authoritarianism, as preconditions for religious conviction (ibid.: 190-198).

For Ambedkar, Buddhism narrates a modern normative perspective of social solidarity as an ally of democratic politics. His perspective on Buddhism is an outcome of critical readings, both on its own terms and through its relationship to liberalism and socialism. ${ }^{40}$ He argued that Buddhism improved over the one-sidedness of liberal individual liberty and socialist material equality. Against Western liberalism, he saw society (and therefore, religion) and politics as entangled. He moved beyond liberalism in viewing the bonds of civil society as voluntary, rather than natural or spontaneous (Ambedkar 1990). Against liberal theory, Ambedkar offered a social view of religion distinguishing between doctrine or ritual and a moral commitment to solidarity. The latter had to be reconciled with the modern ideals of liberty, equality and fraternity. ${ }^{41}$ Ambedkar, unlike Habermas, demonstrates the possibility of citizens reconciling their religious social identities with their political ones. Hence, he critiqued the socialist repudiation of religion as an outcome of an exclusive focus on economic-material well-being (Ambedkar 2002: 176-179). He credits the socialist experiment in the then Soviet Union as leading to equality among human beings. However, such material equality cannot confront caste inequality. Nor can it annihilate the spiritual aspiration motivated by religion (Ambedkar 2010: 21). Ambedkar also cautioned against spirituality degenerating into a quest for other-worldly salvation. By encouraging superstitions and rituals, such a quest would become irresponsible in the face of this-worldly problems such as poverty

36. "There is no sharing among Hindus of joys and sorrows involved in the vital facts of life. Everything is separate and exclusive" (Ambedkar 2010: 36).

37. Ambedkar counts this as $791 / 2$ million in the pre-independence context (Ambedkar 2010: 80), the number is much higher at present.

38. Ambedkar gives a detailed account of conversions to Buddhism of people from working class, privileged and underprivileged caste, "untouchable" $(1957,130)$ and criminal backgrounds. He also discusses how the Buddha allowed women also to join his fold bringing out the transformatory nature of conversion (Ambedkar 1957: 92-112; 125-147). For Ambedkar conversion implied that religion was the outcome of free choice, rather than birth.

39. Ambedkar regards compassion (karuna) as restricted to human beings and fellowship (maitre) as a bond between all living things; but these virtues governing good conduct (sila) also require insight (pradnya) (Ambedkar 1957: 210-214).

40. See Gokhale (2008) for a detailed perspective.

41. He terms the latter as Dhamma following Buddhism. 
and discrimination. Hence, Ambedkar suggests a responsible pursuit of religion in whose spirit he also critiqued Buddhism for inconsistently upholding rebirth as it militates against caste equality (Ambedkar 1957: xli-xlii). His reinvented Buddhism differed with the prevailing Buddhist clergy and was influenced by syncretic religious traditions in India. Unlike Habermas, Ambedkar concretely spelled out the possibility for critically assessing the cognitive claims of religion.

Ambedkar goes beyond Habermas in working out a critique of liberty, equality and fraternity from a religious perspective, and critiquing religion through these modern ideals. He stressed "the consistency and consonance between the beliefs and the ideas of the religious sphere and those of the secular" (Rodrigues 1993: 336). He anticipates Cooke's suggestion that a reciprocal translation (of religious and non-religious claims), rhetoric, choice and empirical descriptions be a part of public deliberation. Ambedkar chooses solidarity as a positive ideal to address individualism of Western liberalism and divisiveness of Hinduism. It is embodied in the Buddhist collectivity (Sangh) as openness, inclusiveness, compassion and fellowship (Ambedkar 1957: 305-306). Rather than logical arguments, solidarity is non-discursively revealed through Ambedkar's felt experience and empirical description of the sociology of caste. It is a "perceptual shift" (Cooke 2013: 259) in integrating society, religion, spirituality and politics against Western secularization. Instead of liberal individualism, Ambedkar adopts Buddhist values and stories to resist caste and work towards solidarity as an attainable earthly hope. ${ }^{42}$ It is not merely a liberal or socialist secularized notion as Marx's interpretation of Kant's Kingdom of God on earth is for Habermas. Ambedkar's Buddhist solidarity integrates the religious and the political, in the spirit of Indian secularism. Hence, he consciously chose Buddhism as an alternative to Hinduism for mass conversion of underprivileged castes in $1956 .{ }^{43}$

\section{References}

Ambedkar, B.R. (1957) The Buddha and His Dhamma. Bombay: Siddharth Publication.

Ambedkar, B.R. (1990) Annihilation of Caste New Delhi / Bombay: Arnold Publications.

Ambedkar, B.R. (2002) "Buddha or Karl Marx", in The Essential Writings of B.R. Ambedkar, ed. Valerian Rodrigues, New Delhi: Oxford University Press, p. 171-189.

Ambedkar, B.R. (2010) Philosophy of Hinduism. New Delhi: Critical Quest.

42. It is akin to Kant's rational belief in God as the hope for moral realization. See Cooke (2010: 253-54).

43. I thank Pradeep Gokhale, Sebastian Hüsch and two anonymous reviewers for helpful feedback on this paper. However, its flaws are entirely mine. 
Bhargava, Rajeev (ed.) (1998) Secularism and Its Critics. New Delhi: Oxford University Press.

Bhargava, Rajeev (2007) "The Distinctiveness of Indian Secularism", in The Future of Indian Secularism ed. T.N. Srinivas, New Delhi: Oxford University Press, p. 20-53.

Bhargava, Rajeev (2015) “We (in India) Have Always Been Post-Secular”, in Michael Rectenwald, Rochelle Almeida, and George Levine (eds.), Global Secularisms in a Post-Secular Age. Boston / Berlin: Walter de Gruyter Inc., p. 109-135.

Bhatt, Chetan (2001) Hindu Nationalism: Origins, Ideologies and Modern Myths. Oxford \& New York: Berg.

Bhattacharya, Sabyasachi (2016) "Secularism and the State", in Frontline (Jan 20) [http://www.frontline.in/politics/secularism-and-the-state/article8123816. ece?css], (last consulted 12/11/2016).

Bilgrami, Akeel (1994) "Two Concepts of Secularism: Reason, Modernity and Archimedean Ideal”, in Economic and Political Weekly 29 (28) p. 1749-1761.

Bilgrami, Akeel (2016) “Gandhi's Radicalism: An Interpretation”, in Bilgrami, A. (ed.) Beyond the Secular West New York: Columbia University Press, p. 215-245.

Brekke, Torkel (2012) Fundamentalism: Prophesy and Protest in an Age of Globalization. Cambridge: Cambridge University Press.

Casanova, José (2013) “Exploring the Postsecular: Three Meanings of 'the Secular' and Their Possible Transcendence" in Craig Calhoun, Eduardo Mendieta, and Jonathan Van Antwerpen (eds.) Habermas and Religion. Cambridge / Malden (MA): Polity Press, p. 27-48.

Chandhoke, Neera (2015) "Secularism: The Life and Times of a Difficult Concept", in Peter Losonczi and Walter Van Herck (eds.) Secularism, Religion and Politics. New Delhi: Routledge, p. 19-35.

Chatterjee, Partha (1994) "Secularism and Toleration", in Economic and Political Weekly, 29 (28), p. 1768-1777.

Cooke, Maeve (2010) "Salvaging and Secularizing the Semantic Contents of Religion: The Limitations of Habermas's Postmetaphysical Proposal”, in David M. Rasmussen and James Swindal (eds.) Habermas (vol. IV). Los Angeles \& London: Sage, p. 235-258.

Cooke, Maeve (2013) "Violating Neutrality: Religious Validity Claims and Democratic Legitimacy" in Craig Calhoun, Eduardo Mendieta, and Jonathan Van Antwerpen (eds.) Habermas and Religion. Cambridge / Malden (MA): Polity Press, p. 249-274.

Fernée Tadd (2014) Enlightenment and Violence. New Delhi: Sage Publications.

Gehl, Reema (2017) "When God was the face of advertising”, in Mumbai Mirror April 13th, p. 33.

Gokhale, Pradeep (2008) "Dr. Ambedkar's Interpretation of Buddhism”, in P. Gokhale (ed.) The Philosophy of B.R. Ambedkar. Pune: Sugava Prakashan, p. 109-152. 
Habermas, Jürgen 2006 "On the Relations Between the Secular Liberal State and Religion”, in Hent de Vries and Lawrence E. Sullivan (eds.) Political Theologies: Public Religion in a Post-secular World. New York: Fordham University Press, p. 251-260.

Habermas, Jürgen (2008) Between Naturalism and Religion: Philosophical Essays. Cambridge / Malden (MA): Polity Press.

Habermas, Jürgen (2009) Europe The Faltering Project. Cambridge / Malden (MA): Polity Press.

Habermas, Jürgen et al (2010) An Awareness of What is Missing: Faith and Religion in a Post-Secular Age. Cambridge / Malden (MA): Polity Press.

Habermas, Jürgen (2011) “The Political': The Rational Meaning of a Questionable Inheritance of Political Theology", in Eduardo Mendieta and Jonathan Vanantwerpen (eds.) The Power of Religion in the Public Sphere. New York: Columbia University Press, p. 15-33.

Jain, Jyotindra (2017) “Commodity Aesthetics: Soap and Cigarette Advertising in Colonial India”, in Marg 68 (3), p. 50-59.

Jha, Shefali (2002) "Secularism in the Constituent Assembly Debates, 1946-1950", in Economic and Political Weekly, 37(30), p. 3175-3180.

Juergensmeyer, Mark (1993) The New Cold War?: Religious Nationalism Confronts the Secular State. Berkeley: University of California Press.

Juergensmeyer, Mark (2011) "Rethinking the Secular and Religious Aspects of Violence”, in Craig Calhoun, Mark Juergensmeyer, and Jonathan Van Antwerpen (eds.) Rethinking Secularism. Oxford / New York: Oxford University Press, p. 185-203.

Mahmood, Tahir (2017) “Justice by Law”, in Indian Express (April 18), p. 9.

Menon, Dilip (2007) “An Inner Violence: Why Communalism in India is about Caste”, in T. N. Srinivas (ed.) The Future of Indian Secularism. New Delhi: Oxford University Press, p. 60-82.

Menski, Werner (2006) Comparative Law in a Global Context: Legal Systems of Asia and Africa. Cambridge: Cambridge University Press.

Mohammad, Afsar (2013) The Festival of Pìrs: Popular Islam and Shared Devotion in South India. Oxford / New York: Oxford University Press.

Patel, Razia (2009) “Indian Muslim Women, Politics of Muslim Personal Law and Struggle for Life with Dignity and Justice" Economic and Political Weekly (44), p. 44-49.

Rathore, Aakash Singh (2010) "Habermas's Post-secularism: The Penetration / Preservation of the (European) Political Public Sphere", in Aakash Singh Rathore and Peter Losonczi(eds.) Discoursing the Post-secular: Essays on the Habermasian Post-secular Turn. Wien / Berlin: Lit Verlag, p. 75-92.

Rodrigues, Valerian (1993) "Making a Tradition Critical: Ambedkar's Reading of Buddhism” in Peter Robb (ed.) Dalit Movements and Meaning of Labour in India. New Delhi: Oxford University Press, p. 299-338.

Thaper, Romila (2013) “The Secular Mode for India”, in Social Scientist 41, (11/12), p. 3-10. 